\title{
Evaluating the impact of percolated reclaimed water from river-channel reservoir on groundwater using tracers in Beijing, Northern China
}

\author{
Yinghua Zhang ${ }^{1} \mathbb{D} \cdot$ Yilei Yu $^{2}$
}

Received: 29 June 2020 / Accepted: 20 January 2021 / Published online: 7 February 2021

(c) The Author(s) 2021

\begin{abstract}
As an increasingly important aspect of water management, historical dry river-channels, ponds or lakes are operated for the storage of reclaimed water as a landscape with the need for reuse of water. However, the percolated reclaimed water may have an adverse effect on groundwater quality. The aims of this work are to evaluate the potential for using various groundwater constituents or characteristics as tracers of percolated reclaimed water, to clarify the groundwater hydrochemical process with the effect of the reclaimed water recharge, and to estimate the degree to which the infiltrated reclaimed water has mixed with the native groundwater. Results obtained by comparing analysis between the dry season and wet season are presented based on multivariate statistics analysis, correlation of hydrochemical elements, and stable isotopes. The groundwater with the impact of reclaimed water was clustered together with higher $\mathrm{Cl}, \mathrm{K}$ and $\mathrm{NH}_{4}-\mathrm{N}$ concentrations, lower Ca concentrations and more enriched heavy isotopes using unprecedentedly 3D-biplot; The water types of the groundwater change from $\mathrm{Ca}-\mathrm{Mg}-\mathrm{HCO}_{3}-\mathrm{Cl}$, via $\mathrm{Ca}-\mathrm{Na}-\mathrm{Mg}-\mathrm{HCO}_{3}-\mathrm{Cl}$ to $\mathrm{Na}-\mathrm{Ca}-\mathrm{Mg}-\mathrm{Cl}-\mathrm{HCO}_{3}$ with increasing reclaimed water percolated into the groundwater; the most useful tracers for evaluation of the fate and mixing of reclaimed water are chloride ion and oxygen-18 and chloride ion is more accurate than oxygen-18 to quantify the recharge source of the groundwater from the reclaimed water; using a two-end-member mixing model to calculate the reclaimed water discharged into the groundwater, the proportion of reclaimed water in groundwater is up to $94 \%$ near the unlined riverbed and up to $43 \%$ far from it. These results demonstrate the potential of the combined application of multivariate statistics analysis, traditional hydrochemical analysis and isotopes to assess the percolated reclaimed water in the groundwater, especially using 3D-biplot to determine the spatial water quality changes defined by the different factors.
\end{abstract}

Keywords Reclaimed water $\cdot$ Groundwater $\cdot$ Multivariate statistics analysis $\cdot$ Tracer $\cdot$ Isotope $\cdot 3$ D-biplot

\section{Introduction}

In Beijing (Northern China) as in other parts of the world, water scarcity is a serious concern. Groundwater is one of the main sources of drinking water and there are increasing demands for water of suitable quality and quantity for other purposes. In order to alleviate the shortage pressure on

Yinghua Zhang

zhangyinghua@igsnrr.ac.cn

1 Key Laboratory of Water Cycle and Related Land Surface Processes, Institute of Geographic Sciences and Natural Resources Research, Chinese Academy of Sciences, Beijing 100101, China

2 Institute of Wetland Research, Chinese Academy of Forestry, Beijing 100091, China water resources, reclaimed water (recycled water or treated wastewater) has been used for agriculture irrigation, heavy industry, landscape water and preventing seawater intrusion in coastal regions (Kass et al. 2005; Katz and Griffin 2008). With the economic and social development and population rapidly increasing in recent years and foreseeable increasing amount of treated wastewater from municipal wastewater treatment plants in future, there is a growing interest in using recycled water for landscape water in large cities. Percolation of the landscape water into subsurface will replenish the local groundwater, however, in some parts of the world, it may not be economically feasible to treat recycled water to drinking standards prior to recharging groundwater aquifer, and where lower quality recycled water recharges groundwater, information is needed regarding the migration and fate of contaminants present in the recycled water, especially where 
groundwater is near the source of drinking water. There are several Beijing examples involving the discharge of secondary treated wastewater into the historical dried river channels for landscape purposes (Zheng et al. 2015). Public concern has been raised about the complexity of predicting the effects of natural processes on reclaimed water recharged to an aquifer (Candela et al. 2007; Lapworth et al. 2012; Estevez et al. 2016). The impact of injected recycled water on the groundwater quality has thus become a research focus over the recent years (Bekele et al. 2019; Vanderzalm et al. 2013; Vodyanitskii and Yakovlev 2016). Large uncertainties exist in determining the key processes controlling hydrochemical transformations in groundwater in the recharge area; therefore, there is keen interest in clarifying the mechanisms controlling water quality changes to obtain a safe and efficient supply of reclaimed water.

The main processes controlling contaminants during migration of reclaimed water into groundwater are sorption, ion exchange, and microbial degradation or transformation (Page et al. 2010; Ginige et al. 2013) and the combined effects of these controlling factors on groundwater quality are very complicated and uncertain (Burg and Guttman 2019; Narr et al. 2019). Multivariate statistical analysis and conventional graphical techniques are commonly used to study the spatio-temporal characteristics of groundwater chemistry and identify their key controlling factors (Masoud 2014; Liu et al. 2017; Moeck et al. 2016). Q-mode hierarchical cluster analysis (HCA) is used to identify the recharge sources, pollution sources, water-rock interaction and ion exchange reactions (Yidana et al. 2012; Singh et al. 2013), factor analyses (FA) is applied to compare the variations of principal water quality component among these clusters (Huang et al. 2010; Gbolo and Gerla 2013) and biplot method was constructed to determine the spatial water quality distribution defined by the different factors (Ceschin et al. 2012; Mohamed et al. 2015). Graphical techniques are used to infer the factors impacting water quality, such as the interrelationship plots of different parameters (Srinivasamoorthy et al. 2008; Rao et al. 2013), Gibbs plot (Redwan et al. 2016) and Piper/Stiff diagrams (Charles and Belitz 2003). Several tracers or indicators are used in combination to provide supporting or independent lines of evidence for reclaimed water fluxes in groundwater (Quiers et al. 2014; Baijali et al. 2017; La Salle et al. 2005; Engelhardt et al. 2014), as reclaimed water may contain different tracers' constituents than does native groundwater.

The effects on groundwater quality of the aquifers of differing lithology or degree of confinement and the infiltration of reclaimed water into groundwater are very complex and ambiguous. Due to the handful of groundwater samples collected and analytes analyzed and the real hydrological data containing outliers, a multivariate statistical method offers several advantages over other methods of providing a representative and reliable estimation of the water quality based on any number of variables, and these variables can be of any type (chemical, physical, biological; distributed or non-distributed). Three-dimension biplot (3D-biplot) can thus provide a more holistic approach to sample comparison than most other methods and explain the correlation amongst a large number of variables in terms of a small number of factors without losing much information. The output of the 3D-biplot can be displayed unambiguously as a relationship of any given site or sample to any group, to assess spatial variability and to detect subtle changes in hydrochemistry simultaneously in a more clear format than that of twodimension biplot used usually by former researchers. The results of the multivariate statistical analysis conjunct with hydrochmical graphical diagrams and isotopic tracing can thus be more readily interpreted in the geological or hydrochemical context than the solitary method.

The combination of multivariate analysis, ion relationships and stable isotopes is used to achieve the following main aims of this study: (1) to determine the geochemical factors and mechanisms controlling the chemical composition of groundwater in the study area, (2) to evaluate the effect of percolated reclaimed water mixed with the groundwater, (3) to quantitatively estimate multi-recharge resources in groundwater based on ionic constituents and isotopes. Observation wells were built around river channels by water managers to monitor the percolation of reclaimed water. The present study will obtain a deeper insight into hydrogeochemical changes in groundwater and provide significant information on the quantity, fate, or impact of the reclaimed water. The results are needed by water managers, especially in the study area where groundwater is the main source of drinking water and there are increasing demands for suitable quality water.

\section{Material and methods}

\section{Study site}

Beijing is located at $39^{\circ} 26^{\prime}-41^{\circ} 03^{\prime} \mathrm{N}$ and $115^{\circ} 25^{\prime}-117^{\circ} 30^{\prime}$ $E$ in the northwest part of the North Plain of China, consisting of mountainous areas and the Beijing Plain (Fig. 1). The Beijing Plain is partly surrounded in the northeast, north and northwest by the Yanshan Fold and the Taihang swell to the west. Local precipitation occurs largely in summer from June to September, which accounts for $70-80 \%$ of the annual amount. Mean annual precipitation ranges from 500 to $600 \mathrm{~mm}$ and mean potential evaporation ranges from 1100 to $1800 \mathrm{~mm}$ (Liu et al. 2011).

The study area is on the foot plain of Yanshan Mountains and located in the alluvial and proluvial fan of the Chaobai River, which is one of the main river fan deposits in the 


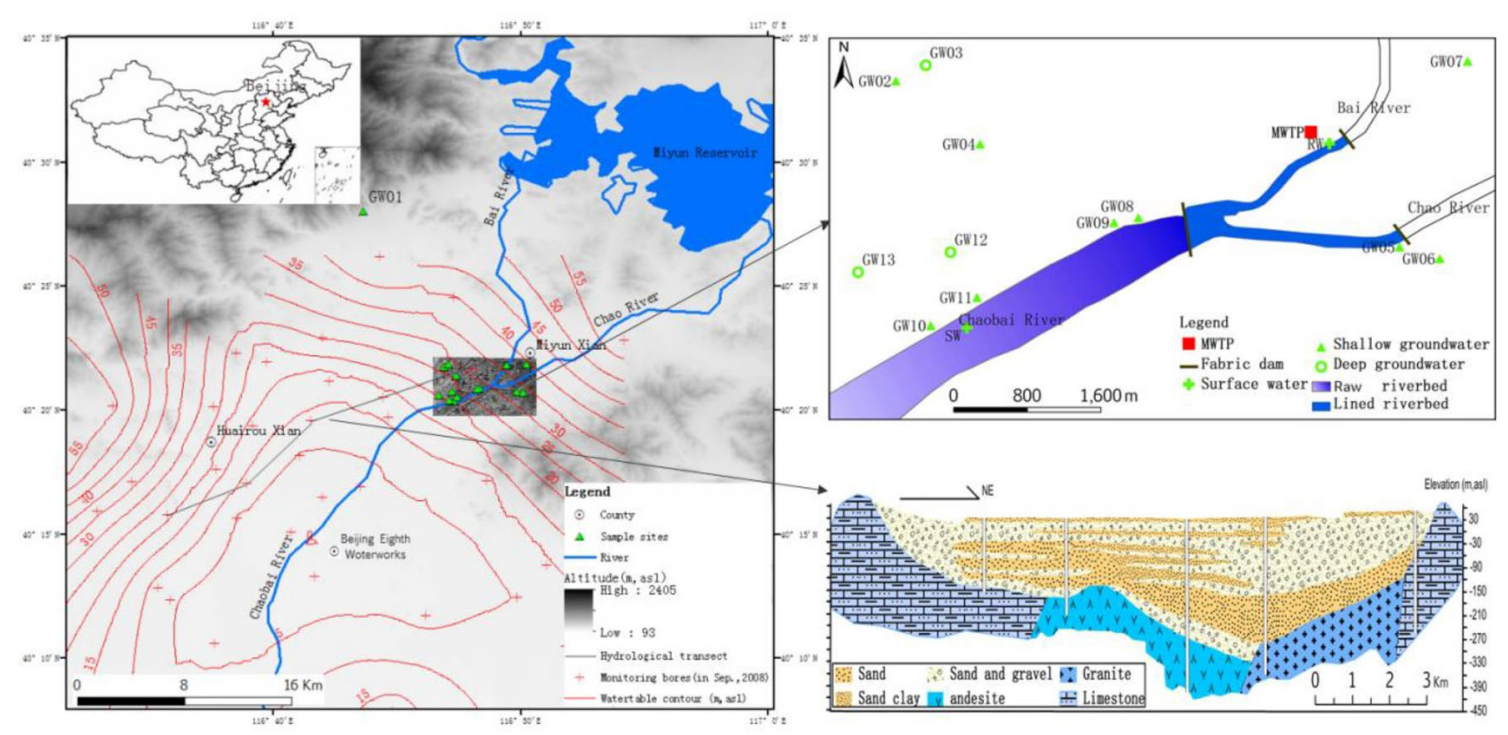

Fig. 1 The location and sampling sites of the study area in Beijing, China

Beijing Plain. The Chaobai River has two tributaries (the Chao and Bai River) in the study area and was dry from 1999 to 2006 due to the continual dry weather and impoundment of the Miyun Reservoir. Since 2006, the Chaobai River, with no water from upstream, is mainly fed with reclaimed water introduced from Miyun Wastewater Treatment Plant (MWTP), where wastewater is treated in a membrane bioreactor (MBR). Reclaimed water, 26,000-70,000 $\mathrm{m}^{3} /$ day, is released into the river channel and was stored in river-channel reservoir as landscape water by inflatable fabric dams ( $3 \mathrm{~m}$ high) built across the channel. The bottom of the channel was covered with impermeable materials (the permeability coefficient $K$ of $10^{-8}-10^{-11} \mathrm{~cm} / \mathrm{s}$ ) between the dams. However, any overflow released into the down-gradient natural river channel all year around infiltrates into subsurface from the last dam and almost disappears at the surface water (SW) sampled site (Fig. 1). Thus, the groundwater is probably bound to be affected by the infiltration of reclaimed water from these natural river channel and riverbanks.

In the mountainous area, Cambrian and Ordovician limestone, Proterozoic dolomite and granulite-amphibolite facies metamorphite of the Archean group are the most widespread rock types, and Jurassic andesite and Proterozoic-Mesozoic rapakivi granite are the main igneous rock types. Especially the igneous rocks are much richer in alkali and potassium than in other area of the world (Yu 1990). In the Beijing Plain, the Quaternary alluvial-pluvial plain of the Chaobai River mainly consists of sandy gravel with a thickness from 100 to $400 \mathrm{~m}$ (Cai et al. 2009a, b). In the study area, river sediments are mainly composed of cobble and boulder with the hydraulic conductivity larger than $100 \mathrm{~m} /$ day. There are three aquifers (sand and gravel) separated by aquitards (silty and slightly sandy clay) with different depths in the plain area of the Chaobai River Basin (Fig. 1). The first aquifer is similar to the river bed sediments with a layer thickness from 0 to $40 \mathrm{~m}$ and overlies a semi-confined aquifer consisting of gravel and rubble with a layer thickness from 50 to $80 \mathrm{~m}$. The confined aquifer is mainly composed of sandy gravel and coarse sand and located at a depth greater than $120 \mathrm{~m}$, even up to $400 \mathrm{~m}$. However, in the study area, which is in the piedmont of the Chaobai River Basin, there is usually only one aquifer above $80 \mathrm{~m}$, and only in a few places that are $1000 \mathrm{~m}$ away from the river channel in the vertical direction, where there are two aquifers as in the plain area due to the presence of the lenses of aquitards. The groundwater level of each aquifer is greater than $20 \mathrm{~m}$ below the surface in the study area. As shown in Fig. 1, the contours of the phreatic water table in September 2008 indicate that regional groundwater flows from north and northwest to south and southeast, but changes near the Beijing Eighth Waterworks, which lies to the south of the study area and uses groundwater as its main source of water supply. As a consequence of groundwater overexploitation, there is a large-scale cone of depression around the waterworks (Fig. 1).

\section{Collection and analysis of water samples}

To assess the factors controlling the regional groundwater chemistry for the study area, historical head data from observation wells were provided by the Department of Water Resources, Beijing Water Science and Technology Institute, and a series of monitoring bores screened over different depths from a monitoring network were sampled monthly from January to September in 2010 for a range of chemical 
and isotopic constituents (Fig. 1). The monitoring network is composed of two water quality monitoring sections, one of which (GW07-GW11) is along the groundwater flow direction and the other (GW02, GW04, GW05 and GW06) crosses the river channel. The monitoring wells with a depth less than $60 \mathrm{~m}$ are screened in the shallow aquifer. Taking the possible evaporation influence of river water into account, the reclaimed water (RW) from the discharge outlet was collected at the same time and surface water (SW) was also sampled in February and August 2010 only for isotopes analysis. For the sake of contrastive analysis, three wells (GW03, GW12 and GW13) with depth more than $120 \mathrm{~m}$ were also sampled in February and August 2010. The water sample (GW01) from the metamorphic bedrock aquier was synchronously collected from a well with $20 \mathrm{~m}$ depth in a mountain area as the background groundwater (unaffected groundwater) for hydrochemical analysis (the GW01 sample in August for hydrochemistry analysis was lost). All the wells with inner diameter of $25 \mathrm{~cm}$ were pumped by a submersible pump using the low-flow purging technique. The physical parameters measured in situ before sample collection included $\mathrm{pH}$, electrical conductivity (EC) and temperature $(T)$ using a portable multisensory meter, whose sensor was installed in the flow cell. Water was pumped through the flow cell at a flow rate which ensured that a smooth, non-turbulent flow of water passed across the sensors. The depths water purged from range from 5 to $10 \mathrm{~m}$ below groundwater level. Results were recorded once the readings stabilised after 15-45 min, and then groundwater samples were collected. Measuring physical parameters before sample collection ensured that the pump was well-flushed with sample water, and the samples collected were representative of current groundwater conditions from within the aquifer (Bekele et al. 2009).

Precipitation samples were collected after each rainfall event since 12 January 2006 for deuterium and oxygen-18 isotopes analysis at the Institute of Geographic Sciences and Natural Resources Research(IGSNRR, 116.38 E, 40.00 N), Chinese Academy of Sciences (CAS), Beijing, China. The rainfall was recorded automatically by a rain gauge at the same time and the sampling procedure is described in detail in a previous study (Liu et al. 2011). The precipitation samples in 2010 were also used for hydrochemical analysis including $\mathrm{Cl}^{-}, \mathrm{SO}_{4}{ }^{2-}, \mathrm{K}^{+}, \mathrm{Na}^{+}, \mathrm{Ca}^{2+}$ and $\mathrm{Mg}^{2+}$.

The concentration of bicarbonate $\left(\mathrm{HCO}_{3}{ }^{-}\right)$was determined by titration under the addition of sulfuric acid $(0.02 \mathrm{~mol} / \mathrm{L})$, and endpoint titration with methyl orange as an indicator. All water samples were filtered through a 0.45$\mu \mathrm{m}$ Millipore membrane filter. Total dissolved solid (TDS) content is determined by evaporating to dryness at $180{ }^{\circ} \mathrm{C}$. The major cations including $\mathrm{K}^{+}, \mathrm{Na}^{+}, \mathrm{Ca}^{2+}$ and $\mathrm{Mg}^{2+}$, were determined using inductively coupled plasma optical emission spectrometry (ICP-OES, PerkinElmer Optima 5300DV,
USA). Major anions including $\mathrm{Cl}^{-}, \mathrm{SO}_{4}{ }^{2-}$, and $\mathrm{NO}_{3}-\mathrm{N}$ were determined by ion chromatography (IC, Shimadzu LC10ADvp, Japan). The detection limits of ICP-OES and IC were $1 \mu \mathrm{g} / \mathrm{L}$ and $0.1 \mathrm{mg} / \mathrm{L}$, respectively. $\mathrm{NH}_{4}-\mathrm{N}, \mathrm{NO}_{2}-\mathrm{N}$ and total nitrogen (TN) were determined by UV spectrophotometry (HACH DR5000, USA). The detection limits of $\mathrm{NH}_{4}-\mathrm{N}, \mathrm{NO}_{2}-\mathrm{N}$ and $\mathrm{TN}$, respectively, were $0.02,0.001$ and $0.1 \mathrm{mg} / \mathrm{L}$. Analytical precision was within $1 \%$, and ion balance errors were $<5 \%$ for samples. An isotopic liquid water and continuous water vapor analyzer (LGR, USA) was used to carry out the isotopic composition measurements at the IGSNRR, CAS. The $\delta^{18} \mathrm{O}$ and $\delta \mathrm{D}$ values are reported as per mil $(\% \circ)$ deviations from the international standard V-SMOW (Vienna Standard Mean Ocean Water). The measurement accuracy was consistently $\pm 1 \%$ for $\delta \mathrm{D}$ and $\pm 0.1 \%$ for $\delta^{18} \mathrm{O}$.

\section{Data analysis}

The isotopic data from 12 January 2006 to 23 November 2015 of precipitation was used for the local meteoric water line (LMWL). The rainfall-weighed average isotopic and ionic constituents in rain were also used for the following analysis along with this sampling campaign and the precipitation data from November to April is characterized as dry season and that from May to October as wet season.

To identify the significant groundwater chemical characteristics, hydrogeochemical classification diagrams and some graphical methods have been used to help in understanding the origin and evolution of groundwater chemistry in the aquifer flow system. The physical and chemical parameters were standardized using the mean and standard deviation ( $z$-scores) to avoid the effect of dimensions of values prior to the multivariate analysis (Lanzante 1996). Kaiser-Meyer-Olkin (KMO) index was proposed for a measure of sampling adequacy (Cerny and Kaiser 1977) and Bartlett test of sphericity (Jackson 1991) were conducted to ensure the relevance of the results and usefulness of the FA (Parinet et al. 2013). After data screening, they met the conditions required in FA with KMO index of 0.71 and the Bartlett's test significance probability of 0.003 in this study, indicating that FA could be considered appropriate and useful tool to provide significant reduction in the dimensionality of the data. HCA was used to identify the spatial variation between the sampling sites based on the level of physiochemical parameters. Cluster analysis was performed by Ward's method using Euclidean distance as a similarity measure. Q-mode HCA was used to classify the different samples into clusters according to the similarity of multiple parameters among samples, FA was used to simplify the number of variables into groups of variables (factors), which may represent different sources and a biplot allows to visualize the magnitude and sign of each variable's contribution 
to the different principal component factors, and how each observation is represented in terms of those components. The use of variables that have specific relationships (directly related) can cause undesirable redundancies in HCA and FA (Guler et al. 2002). To graphically clarify the correlation among variables and factors more clearly in 3D-Biplot, $\mathrm{Na}, \mathrm{Mg}, \mathrm{TN}, \mathrm{EC}$ and $\mathrm{SD}$ were excluded from HCA and FA without a significant impact on the results, because these analytes varied strongly with others, for example, roughly $90 \%$ of the variation in $\mathrm{Na}$ could be explained by variation in $\mathrm{Cl}(r=0.95, p=2.44 \mathrm{E}-07)$ and roughly $95 \%$ of the variation in $\mathrm{Mg}$ could be explained by variation in $\mathrm{Ca}(r=0.97$, $p=6.11 \mathrm{E}-09$ ) with Pearson correlation and Student's $t$ test (Hirsch et al. 1982). The factor analysis was performed with Matlab R2012a software. In addition, graphical techniques such as Piper diagram and different parameters' relationship chart/table were used to clarify the characteristics of physiochemistry and the hydrochemical processes.

Hydrochemistry and water stable isotopes were always used to quantify recharge from different sources in multiaquifer systems via mixing analyses (Yamanaka et al. 2011; Peng et al. 2014; Filippini et al. 2015; Murgulet et al. 2016). The contributions from different sources to a mixture were quantified using a end-member mixing model based on the following mass balance equations for water and tracers:

$$
\left\{\begin{array}{l}
\sum_{i=1}^{e} f_{i}=1 \\
\sum_{i=1}^{e} C_{i j} f_{i}=C_{m j}(j=1,2,3, \ldots, n, \quad \text { and } \quad j \geq i-1)
\end{array},\right.
$$

where $C$-tracer concentration, $f$-fraction of different mixing source, subscript $m$-mixture, subscripts $i=1,2,3, \ldots e$, represent different end-member and subscripts $j=1,2,3, \ldots . n$, refers to the different tracers.

\section{Results and discussion}

\section{Multivariate statistical analysis}

All water samples from monitoring wells were classified into four statistically significant groups as shown in the dendrogram in Fig. 2. The water from the metamorphic bedrock aquifer in the mountain area (GW01) and the reclaimed water (RW) are respectively clustered in Group IV and Group III entirely different from the other two groups. Water samples from wells near and along the raw riverbed (GW08, GW09, GW10, GW11) are clustered together in Group II. However, the water samples near the lined riverbed (GW05 and GW06) are in Group I together with the samples far from the riverved (GW02, GW04 and GW07) and the deep groundwater samples (GW03, GW12 and GW13), although those from deep wells are clustered tightly together.

The factor loadings coefficient matrix, maximum likelihood estimates of the specific variances (Spv), the percentage of the total variance (Prop) explained by each principal component factor and its cumulative percentage (Cum) are listed in Table 1, and biplot of variable/factor coefficients and scores (observation and biplot axes) of the three factors are presented in Fig. 3. As shown in Table 1, the three principal factors are cumulatively enough to describe $88.3 \%$ of the total variability in the original data and the $\mathrm{pH}$ and $\mathrm{T}$ are relatively weak to estimate the physio-chemical variance among these samples as all their Spv were larger with 0.25.

The correlation pattern between different variables (biplot vectors) is displayed in the biplot by the product of the lengths of the corresponding arrows and the cosine of the angle between them (Fig. 3). Thus, the correlation is positive if the angle is sharp, negative if the angle is obtuse, and zero if the arrows are perpendicular, and the level of correlation
Fig. 2 Dendrogram generated from HCA of water physicochemical data

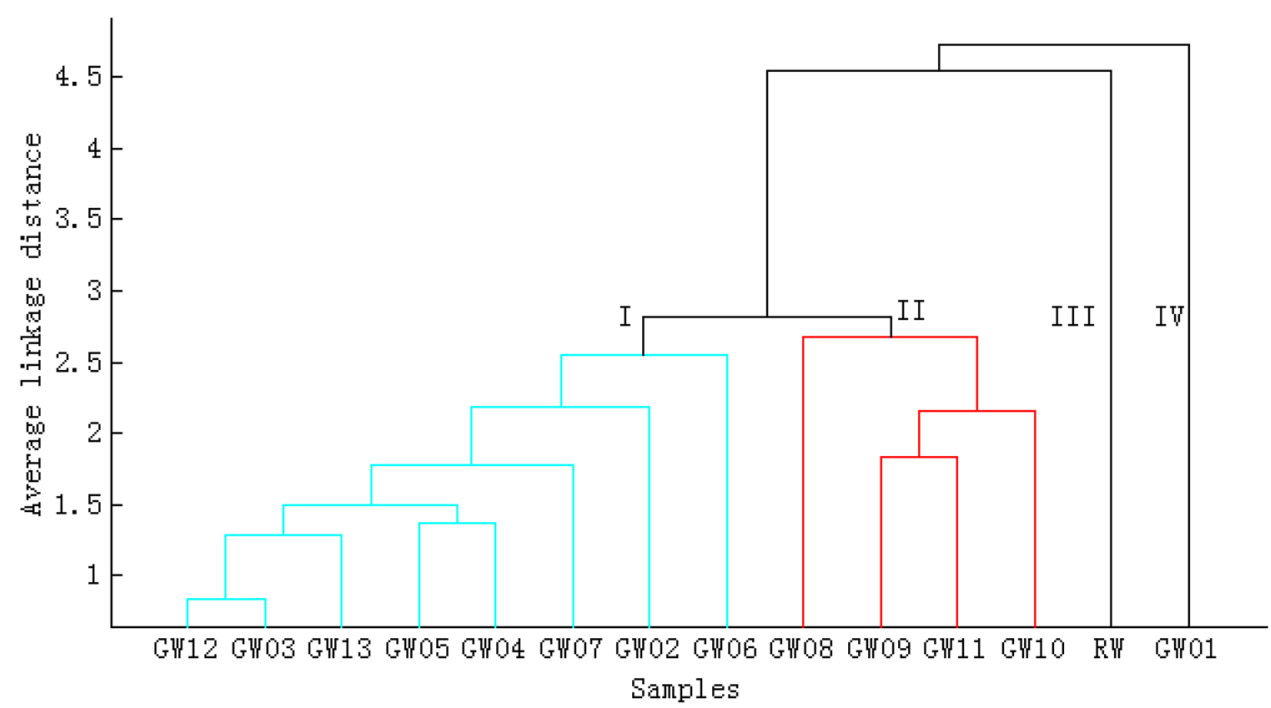


Table 1 Principal component factor and coefficient matrix

\begin{tabular}{lrrrr}
\hline Variables & \multicolumn{1}{l}{$\mathrm{F} 1$} & \multicolumn{1}{l}{$\mathrm{F} 2$} & \multicolumn{1}{l}{$\mathrm{F} 3$} & $\mathrm{Spv}$ \\
\hline $\mathrm{Cl}$ & $\mathbf{0 . 9 1}$ & 0.06 & 0.38 & 0.02 \\
$\mathrm{SO}_{4}$ & $\mathbf{0 . 8 8}$ & 0.26 & 0.16 & 0.13 \\
$\mathrm{HCO}_{3}$ & 0.22 & $\mathbf{0 . 9 4}$ & 0.00 & 0.06 \\
$\mathrm{~K}$ & 0.71 & -0.22 & 0.63 & 0.05 \\
$\mathrm{Ca}$ & -0.18 & $\mathbf{0 . 9 3}$ & 0.22 & 0.06 \\
$\mathrm{NH}_{4}-\mathrm{N}$ & $\mathbf{0 . 8 9}$ & -0.13 & -0.16 & 0.17 \\
$\mathrm{NO}_{3}-\mathrm{N}$ & 0.03 & 0.20 & $\mathbf{0 . 9 3}$ & 0.09 \\
$\mathrm{pH}^{18}$ & -0.64 & 0.33 & 0.48 & $\mathbf{0 . 2 5}$ \\
$T$ & $\mathbf{0 . 9 2}$ & -0.15 & -0.21 & 0.09 \\
Prop $(\%)$ & 0.81 & 0.25 & 0.18 & $\mathbf{0 . 2 5}$ \\
$\mathrm{Cum}(\%)$ & 48.82 & 21.28 & 18.20 & \\
\hline
\end{tabular}

The bold identifies the characteristic variable

with a variable tend to be lower if the variable is closer to the origin of the plot. One can therefore obtain the approximate order of the correlations of one sample (biplot point) with a particular variable or factor (biplot axis) from the scalar product between them, which is the length of the projection of the sample point (biplot point) onto the variable (biplot vector) or the factor (biplot axis) and their projections, multiplied by the length of the corresponding biplot vector or axis (Braak 1990; Beh 2012). The above rules were provided for interpreting the 3D-biplot graphically.

Using these above rules, we see from Fig. 3 that in the approximation used, three groups of variables are seen to be highly positively correlated (the angles between them are small): the group of $\mathrm{pH}, \mathrm{Ca}$ and $\mathrm{HCO}_{3}$ (Group A), the group of $\mathrm{NH}_{4}-\mathrm{N}$ and $\delta^{18} \mathrm{O}$ (Group B) and the group of T, K, Cl and $\mathrm{SO}_{4}$ (Group C). Group B means that isotope enrichment and denitrification occurred during the rapid replenishment of groundwater by reclaimed water. Group $\mathrm{C}$ indicates that compared with groundwater, the enrichment of $\mathrm{Cl}, \mathrm{SO}_{4}$, and especially $\mathrm{K}$ in reclaimed water is more typical than other hydrochemical ions, although other groundwater samples are enriched with $\mathrm{K}$ due to geogenic purposes. Because $\mathrm{T}, \mathrm{SO}_{4}$ and $\mathrm{HCO}_{3}$ are closer to the origin of the plot, the correlations between these three variables and the other variables tend to be small. Group A showed more negative correlation to Group B than to Group C, and a significant positive correlation is revealed between Group B and Group C. There are some differences in analytes between the principal factors and the spatial analytes' groups as shown in Table 1 and Fig. 3. Factor 1 shows strong positive loadings of analytes in Group B and Group C, Factor 2 shows strong positive loadings of analytes in Group A, and Factor 3 shows strong positive loading of $\mathrm{NO}_{3}-\mathrm{N}$.

Group IV displays lower concentrations of almost all analytes compared to the other groups. This indicates that samples assigned to Group IV are generally more dilute and have lower total dissolved solids than samples assigned to other groups. Group III as reclaimed water has higher concentrations of $\mathrm{NO}_{3}-\mathrm{N}, \mathrm{K}, \mathrm{Cl}, \mathrm{SO}_{4}$ and lower concentrations of $\mathrm{Ca}$ and $\mathrm{HCO}_{3}$ than Group II. Group II shows positive weighting of $\mathrm{NH}_{4}-\mathrm{N}$ and negative loading of $\mathrm{NO}_{3}-\mathrm{N}$ indicating the importance of redox potential in the samples, positive weighting of $\mathrm{K}, \mathrm{Cl}, \mathrm{SO}_{4}$ similar to Group III with higher dissolved solids (reclaimed water) indicating their
Fig. 3 Biplot of correlations among samples and variables for the first three factors identified by factor analysis

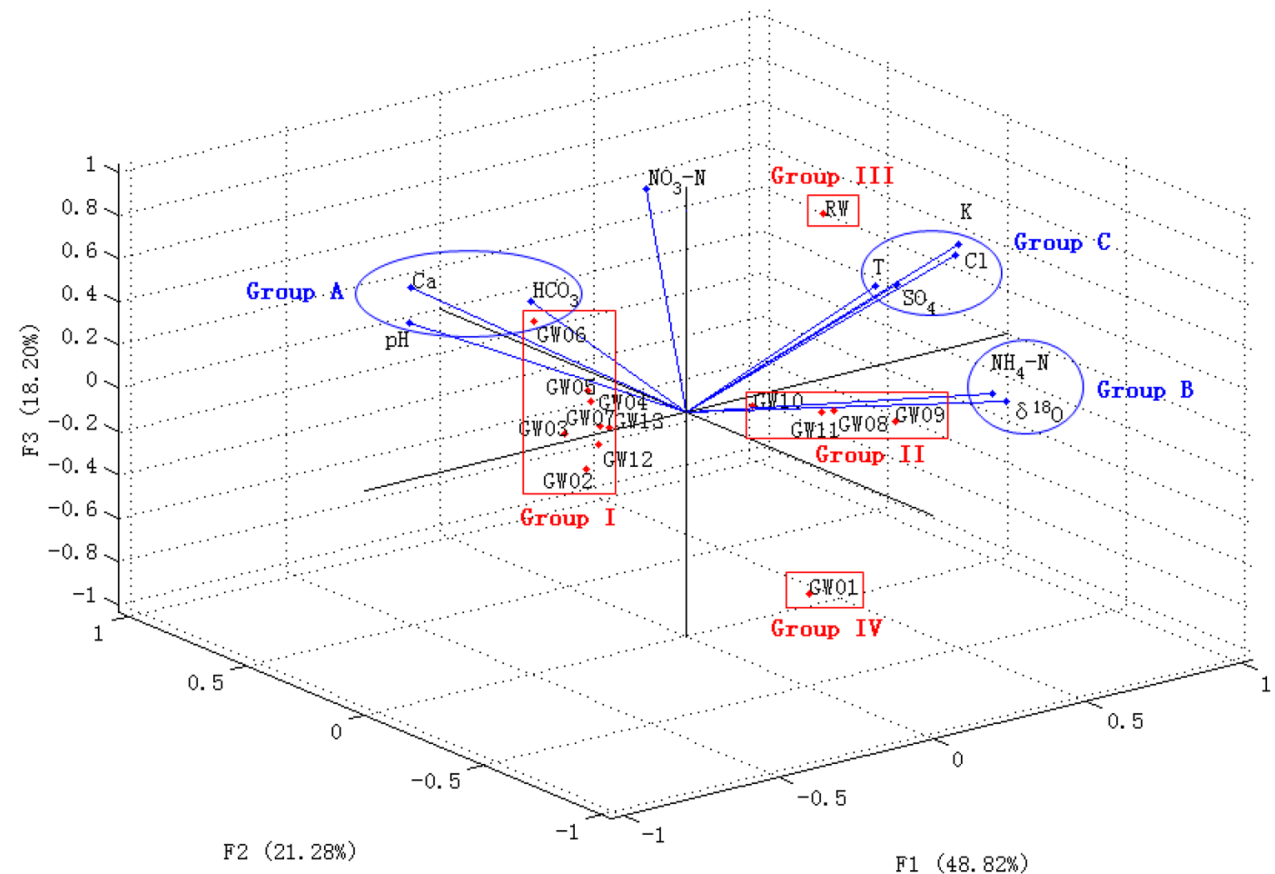

F1 (48. 82\%) 
close relation, and stronger positive weighting of $\delta^{18} \mathrm{O}$ than Group III suggesting the more concentrated waters with evaporation. Group I have a strong positive loadings of $\mathrm{Ca}$ and $\mathrm{HCO}_{3}$ and negative loadings of $\mathrm{K}, \mathrm{Cl}$ and $\mathrm{SO}_{4}$ indicating the water types of aquifer lithology, and the sample GW06 in this group is distinguished from the other samples by its higher $\mathrm{NO}_{3}-\mathrm{N}$ concentration implying the effect of a point pollution source, whereas GW02 is more pristine with the lowest $\mathrm{NO}_{3}-\mathrm{N}$ and $\mathrm{Cl}$ concentration except the water from the metamorphic bedrock aquifer in mountain area (GW01).

\section{Hydrochemical characteristics and processes}

\section{Hydrochemical characteristics}

The physical and chemical characteristics of groundwater in the shallow aquifer vary mainly as a function of location relevant to the groundwater flow system (recharge-discharge zone) and the aquifer lithology. These characteristics are derived from the dissolution of minerals and decomposition of organic material in the soil and phreatic zones by hydrogeochemical processes such as solution-precipitation, sorption-desorption, ion exchange, and organic degradation.

The hydrochemical data of groundwater were plotted on a Piper trilinear diagram, which is commonly used for displaying the main groundwater components at a glance and providing a basis for the descriptive classification of water type (Piper 1944). The Piper plot and water types were analyzed on the base of the results from the software AquaChem 3.70. As seen from Fig. 4, groundwater samples in Group I are very similar to the bedrock groundwater of Group
IV as they are positioned in the same area at the left hand corner of the diamond diagram. Groundwater constituents of deep groundwater (with transparent symbols) in Group I in dry season are identical to those in wet season with $\mathrm{Ca}-\mathrm{Mg}-\mathrm{HCO}_{3}$. Although shallow groundwater (with solid colored symbols) in Group I in dry season have the same water types as those in wet season, GW02, GW06 and GW07 with $\mathrm{Ca}-\mathrm{Mg}-\mathrm{HCO}_{3}$ are different from GW04 and GW05 with $\mathrm{Ca}-\mathrm{Mg}-\mathrm{HCO}_{3}-\mathrm{Cl}$. Groundwater samples in Group II resemble highly to the reclaimed water of Group III because they are positioned in the same area in the middle of the diamond diagram in both seasons. Water type of GW08 and GW09 in dry season is $\mathrm{Na}-\mathrm{Ca}-\mathrm{Mg}-\mathrm{Cl}-\mathrm{HCO}_{3}$ different from $\mathrm{Na}-\mathrm{Ca}-\mathrm{HCO}_{3}-\mathrm{Cl}$ in wet season, but $\mathrm{GW} 10$ and $\mathrm{GW} 11$ have the same water types of $\mathrm{Ca}-\mathrm{Na}-\mathrm{Mg}-\mathrm{HCO}_{3}-\mathrm{Cl}$ in both seasons. Water types of Group III and Group IV are $\mathrm{Na}-\mathrm{Ca}-\mathrm{Cl}-\mathrm{HCO}_{3}(\mathrm{RW})$ and $\mathrm{Ca}-\mathrm{Mg}-\mathrm{Na}-\mathrm{HCO}_{3}-\mathrm{SO}_{4}$ (GW01), respectively.

The shallow aquifer lithology may produce a $\mathrm{Ca}-\mathrm{Mg}-\mathrm{HCO}_{3}$ water, as the lithology derived from decomposed Cambrian-Ordovician limestone and Proterozoic dolomite. Water types changing from $\mathrm{Ca}-\mathrm{Mg}-\mathrm{HCO}_{3}$ to $\mathrm{Ca}-\mathrm{Mg}-\mathrm{HCO}_{3}-\mathrm{Cl}$ of the superficial groundwater near the lined riverbed are caused by the less mixing with the chloride-type reclaimed water. Along the flow lines from the lined riverbed towards the raw riverbed, the change in water type can be seen clearly from $\mathrm{Na}-\mathrm{Ca}-\mathrm{Mg}-\mathrm{Cl}-\mathrm{HCO}_{3}$ to $\mathrm{Ca}-\mathrm{Na}-\mathrm{Mg}-\mathrm{HCO}_{3}-\mathrm{Cl}$ indicating that the mixing of reclaimed water is decreasing along the flow lines. The same water type change from $\mathrm{Na}-\mathrm{Ca}-\mathrm{Mg}-\mathrm{Cl}-\mathrm{HCO}_{3}$ to

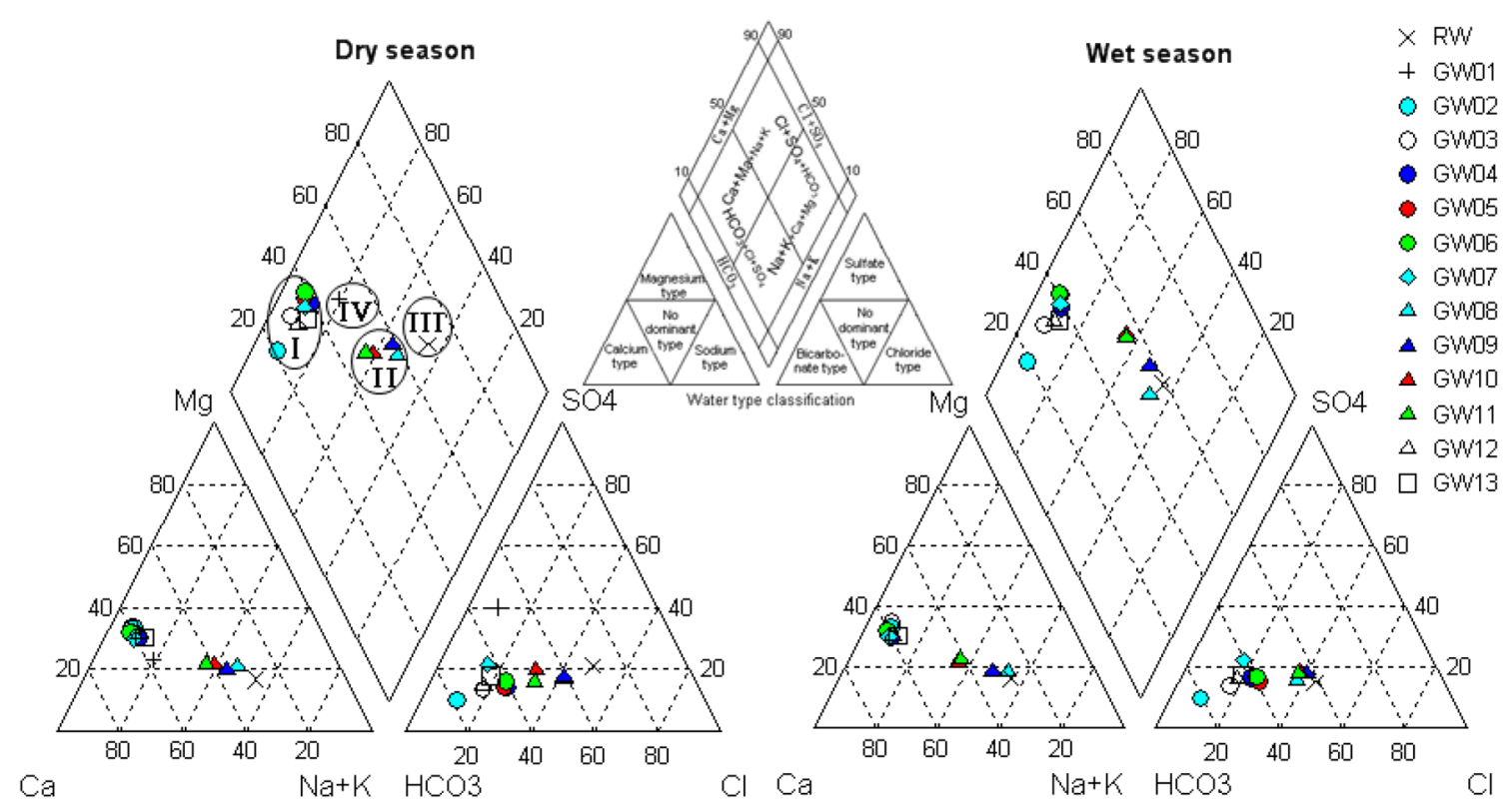

Fig. 4 Piper diagram of water showing the relative proportions of major ions 
$\mathrm{Ca}-\mathrm{Na}-\mathrm{Mg}-\mathrm{HCO}_{3}-\mathrm{Cl}$ also is found from dry season to wet season implying the key role of the rainwater in wet season.

\section{Stable isotopic composition}

Stable isotope data from groundwater, reclaimed water in dry season and in wet season and amount-weighted average rainwater from 2006 to 2015 for Beijing are plotted in Fig. 5a, a', showing the local evaporation line (dashed line with equation) in comparison to the local meteoric water line (LMWL with equation). The 'deuterium excess' used as the index of the evaporation effect on water (Dansgaard 1964), is plotted against TDS to clarify the change of hydrochemistry because of evaporation, dilution and other effects (Fig. 5b, $\left.b^{\prime}\right)$. More intense evaporation in groundwater in dry season results in the local evaporation line much farther from the LMWL in dry season than that in the wet season. The water from the metamorphic bedrock aquifer (GW01) is located on the LMWL in both seasons indicating less evaporation (Dansgaard 1964).

As shown in Fig. 5, the bedrock groundwater of Group IV is depleted with heavy isotopes in the dry season and enriched with heavy isotopes in the wet season and its seasonal isotopic characteristic is similar to that of the precipitation (Liu et al. 2011). The water from the metamorphic bedrock aquifer has lower TDS and approximate 'deuterium excess' of the rain which reflects rainwater since it has undergone little changes. The reclaimed water of Group III has a similar isotopic composition in the dry season and wet season. The reclaimed water has the largest TDS and lower 'deuterium excess' resulting from the evaporation and the biochemical reaction in the process of sewage treatment. The groundwater in Group II is more enriched with heavy isotopes than the other water samples only except the surface water (SW), which was sampled from the intensively evaporated reclaimed water with highly enriched heavy isotopes. It suggests that the groundwater in Group II is mixed with the reclaimed water, thus, the group also has the highest TDS and the lowest 'deuterium excess', and the increasing 'deuterium excess' in the wet season results from the increasing 'deuterium excess' of the reclaimed water and more dilution by rainwater. The isotopes of the groundwater in Group I are clustered together with the bedrock groundwater of Group IV in dry season except GW07 but are scattered entirely in the wet season. Both TDS and 'deuterium excess' in Group I are scattered entirely whether in the dry season or in the wet season. The distributions of the isotopes, TDS and 'deuterium excess' indicate the groundwater's different
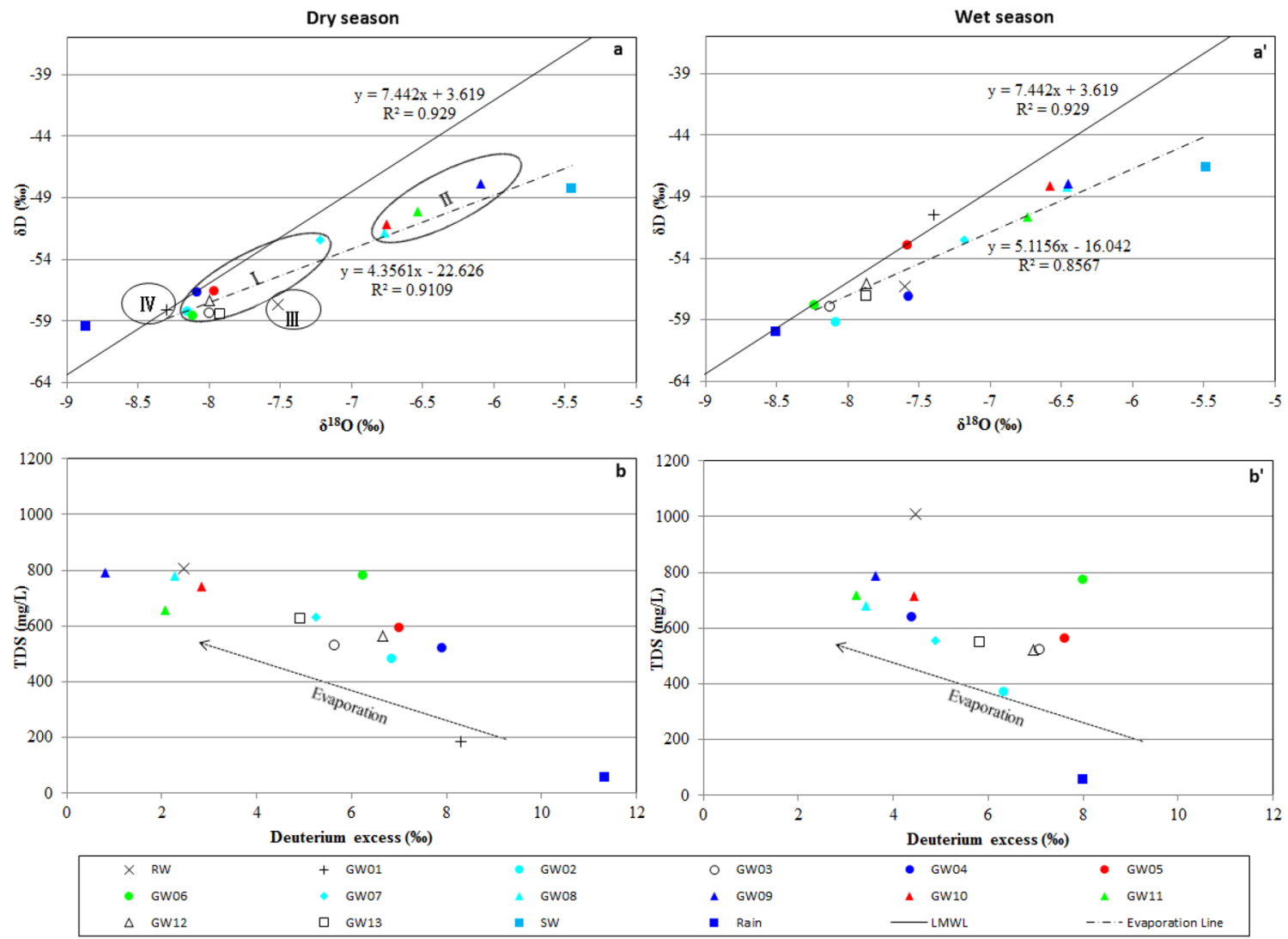

Fig. 5 Isotopic composition and relationship between TDS and 'deuterium excess' in different water 
recharge sources and the influence of different degrees of evaporation in Group I. There are almost no discrepancies of isotopic composition in GW02 between dry season and wet season, and GW02 is far from the river and has lower TDS and higher 'deuterium excess' in both seasons, so GW02 is not affected by the reclaimed water during both seasons. GW04 is located on the LMWL in the dry season and it is clustered together with the reclaimed water completely deviating far from the LMWL in wet season, and it has higher TDS and lower 'deuterium excess' in the wet season than in the dry season. The recharge of the aquifer (GW04) by the river is more intense during the wet season and the effect of recharge and reclaimed water is seen further in the aquifer than during the dry season. GW05 and GW06 deviate little from the LMWL in dry season and are located on it in the wet season implying the key role of rainwater recharging, which also causes the small decreasing TDS and increasing 'deuterium excess'. GW07 has the same isotopic composition and much lower 'deuterium excess' in both seasons in Group I, indicating steady source of groundwater recharge from highly evaporated water. In addition, GW07, as located up hydraulic gradient of the reclaimed water reservoir, has a similar isotopic composition to Miyun Reservoir $(-7.1 \%$ o of $\delta^{18} \mathrm{O}$ and $-51 \%$ of $\delta \mathrm{D}$ ) (Wu et al. 2012) and therefore is recharged mainly by the piedmont surface runoff coming from the occasional discharge of the reservoir. The change of isotopes and TDS are quite limited between the dry and wet seasons for the three deep wells (GW03, GW12 and GW13) as these wells are located in a confined sand and gravel aquifer with a depth greater than $120 \mathrm{~m}$. Little changes are due to the depth of these boreholes which smooth the changes. The results of isotopic analysis are in agreement with those provided by biplot and Piper diagram analysis.

\section{Geochemical processes of groundwater}

To see the relation between the aquifer materials and the chemical composition of the groundwater within the aquifer, especially with the effect of mixtures of different waters (enrichment by reclaimed water and dilution by rainwater or a fresher groundwater), absolute values of concentrations of the different water constituents is of marginal use in the interpretation of water quality data. To compensate for dilution and other effects, the use of ratios is recommended (Hounslow 1995). Some methods of plotting ratios are used graphically to visualise the hydrochemical processes and to discern the source of ions (Kass et al. 2005).

In dealing with ratios it is often useful to compare them with a standard and seawater is probably the best choice as the standard for many investigations (Hounslow 1995). In the study area, the K/Na ratios of groundwater are larger than the $\mathrm{K} / \mathrm{Na}$ ratio of seawater with a constant of 0.02 (Fig. 6a, $\left.\mathrm{a}^{\prime}\right)$ and all the $(\mathrm{K} / \mathrm{Na})_{\text {Sample }} /(\mathrm{K} / \mathrm{Na})_{\text {Seawater }}$ ratios of groundwater are larger than two indicating that $\mathrm{K}$ enrichment has occurred, so there is enriched with potassium in groundwater because of the higher $\mathrm{K}_{2} \mathrm{O}$ in aquifer rocks (Cai et al. 2009a, b). The $\mathrm{K} / \mathrm{Na}$ ratio is negatively correlated with $\mathrm{Cl}$ concentration indicating that potassium is more easily sunk by plants or clays while the $\mathrm{Cl}$ is very conservative (Fig. 6a, $\mathrm{a}^{\prime}$ ). The common clay reaction for potassium is clay $+\mathrm{K}^{+} \rightarrow$ illite. The $\mathrm{Na} /(\mathrm{Na}+\mathrm{Cl})$ ratio of the groundwater in Group IV has the largest value greater than 0.5 and the $(\mathrm{Na}+\mathrm{K}-\mathrm{Cl}) /(\mathrm{Na}+\mathrm{K}-\mathrm{Cl}+\mathrm{Ca})$ ratio is greater than 0.2 and less than 0.8 , showing that the sodium and potassium sources are from plagioclase weathering rather than halite. Group II has a similar ratio of $\mathrm{Na} /(\mathrm{Na}+\mathrm{Cl})(>0.5)$ and $(\mathrm{Na}+\mathrm{K}-\mathrm{Cl}) /(\mathrm{Na}+\mathrm{K}-\mathrm{Cl}+\mathrm{Ca})(>0.2$ and $<0.8)$ with the Group IV, however, the sodium and potassium sources are from mixing of the reclaimed water (Fig. $6 \mathrm{~b}, \mathrm{c}$ ). The groundwater Group I have the $\mathrm{Na} /(\mathrm{Na}+\mathrm{Cl})$ ratio lower than 0.5 (Fig. 6b, b') and the TDS greater than $500 \mathrm{mg} / \mathrm{L}$ (except GW02 in wet season) (Fig. 5b, b') indicating regeneration or reverse ion exchange happens as the following reaction of $\mathrm{Na}_{2}$-clay $+\mathrm{Ca}^{2+} \leftrightarrow \mathrm{Ca}^{2+}$-clay $+2 \mathrm{Na}^{+}$. The reverse ion exchange also results in a negative correlation between $\mathrm{Na} /(\mathrm{Na}+\mathrm{Cl})$ ratio and $\mathrm{Ca}$ as shown in Fig. $6 \mathrm{~b}, \mathrm{~b}^{\prime}$. GW02 has the $\mathrm{Na} /(\mathrm{Na}+\mathrm{Cl})$ ratio $(0.44$ in dry season and 0.47 in wet season) almost closest to that of seawater (0.46) and local rainwater $(0.49)$, the highest ratio of $\mathrm{Na} /(\mathrm{Na}+\mathrm{Cl})$ to Ca concentration (Fig. 6b, $\mathrm{b}^{\prime}$ ) and the highest ratio of $\mathrm{Mg}$ / $(\mathrm{Mg}+\mathrm{Ca})$ in Group I, indicating that little ion exchange happens in GW02 between sodium and calcium. The $\mathrm{Mg}$ / $(\mathrm{Ca}+\mathrm{Mg})$ ratio of all groundwater samples is less than 0.5 , the $\mathrm{Ca} /\left(\mathrm{Ca}+\mathrm{SO}_{4}\right)$ ratio is larger than 0.5 , and the TDS is greater than $500 \mathrm{mg} / \mathrm{L}$ (Table 2 and Fig. 5), indicating the calcium and magnesium sources are from limestone-dolomite weathering leading to the positive correlation between $\mathrm{Ca}$ and $\mathrm{HCO}_{3}$ (Fig. 6d). The discrepancies of the ion ratios in groundwater between the dry season and wet season are similar to that of isotopic composition, which results from the same reason as discussed in hydrochemical characteristics and isotopic composition analysis.

\section{Groundwater recharge estimates using tracers}

Groundwater recharge and discharge patterns in the study area are interpreted by synthesizing results from all of the above analysis. The direction of groundwater flow in the study area is generally from northeast to southwest (Fig. 1). Groundwater in Group II has higher $\mathrm{NH}_{4}-\mathrm{N}$, TDS and $\mathrm{Cl}$ concentration (Figs. 3, 5), the same water types with the reclaimed water (Fig. 4), more enriched heavy isotopes and lower 'deuterium excess' (Fig. 5), which indicate that the groundwater mainly comes from the penetration of the reclaimed water. GW02 has the lowest $\mathrm{NO}_{3}-\mathrm{N}$, TDS and ions concentration in Group I (Figs. 3, 5, 6), the highest 

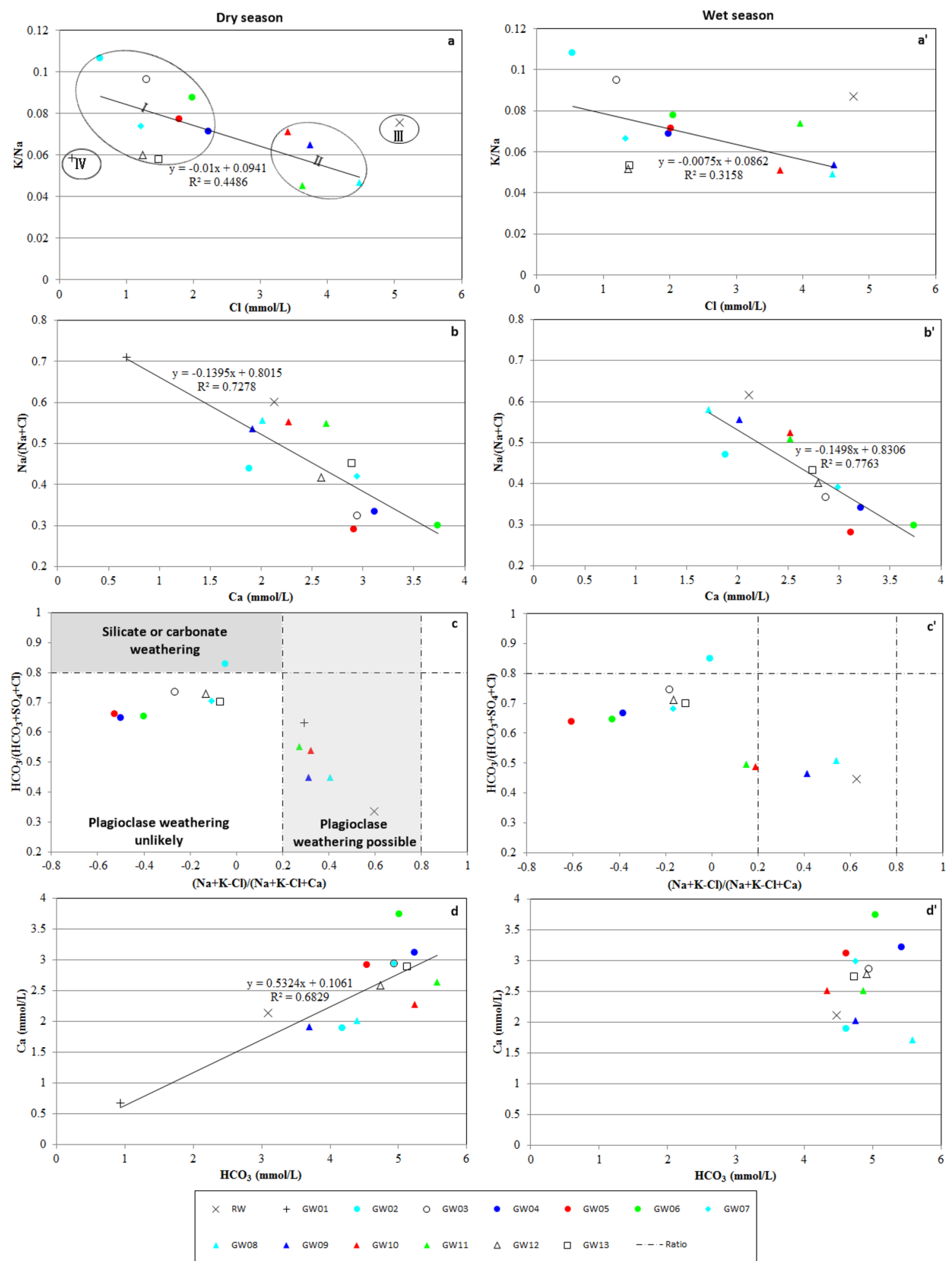

Fig. 6 Diagram of comparison between ion concentration and ion ratios

$\mathrm{HCO}_{3} /\left(\mathrm{HCO}_{3}+\mathrm{SO}_{4}+\mathrm{Cl}\right)($ Fig. $6 \mathrm{c})$, and similar $\mathrm{Na} /(\mathrm{Na}+\mathrm{Cl})$ ratio to seawater and rainwater, which only could be found where the shallow groundwater flow system originating near the direct rainfall recharge areas. This is further supported by the little discrepancies of hydrochemical and isotopic signature between the dry season and wet season (Figs. 5, 


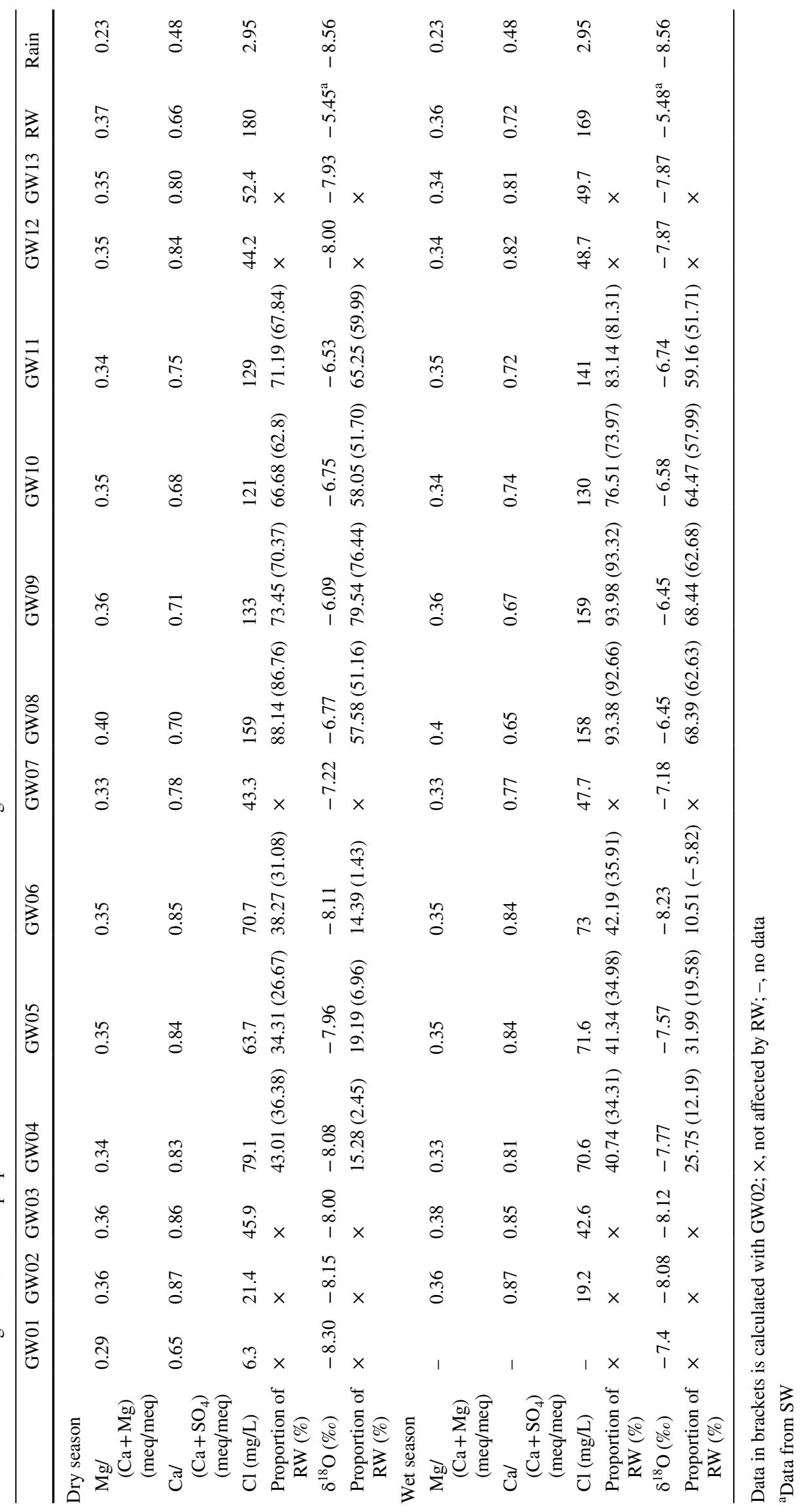


6). It is suggested that GW02 comes completely from the local infiltrated rainfall and its hydrochemical and isotopic constituents could be used as the end-member of the infiltrated rainwater at other sites. GW04 and GW05 are partially replenished by the reclaimed water because the abnormal chloride ion content (Fig. 6a, $\mathrm{a}^{\prime}$ ) and the seasonal change of 'deterium excess' (Fig. 5b, b') and water types (Fig. 4) between dry season and wet season. GW06, located in a livestock farm, is probably contaminated by the point pollution source with the highest $\mathrm{NO}_{3}-\mathrm{N}$ and lower $\mathrm{NH}_{4}-\mathrm{N}$ in groundwater which is distinct from the groundwater in Group II (Fig. 3). GW04, GW05 and GW06 are very little influenced by the reclaimed water and they plot at the same place in the Piper with no changes in composition (Fig. 4). The isotopic and hydrochemical constituents of the deep groundwater (GW03, GW12 and GW13) indicate that the groundwater comes from different recharge sources such as the metamorphic bedrock aquifer, the seepage of Minyun reservoir and local precipitation infiltration (Wu et al. 2012). Overall, the outcome of isotopic analysis is in agreement with the interpretations based on comparisons of ions.

Although the distinctly difference of the $\mathrm{Ca}, \mathrm{Na}$ (significant correlation with $\mathrm{Cl}$ ) and $\mathrm{K}$ concentrations between the reclaimed water and background groundwater (unaffected groundwater) as revealed in Fig. 3, because there are a sink of $\mathrm{K}$, dolomite dissolution and reverse ion exchange during groundwater recharge process in the study area, the above three non-conservative ions are only used as qualitative indicators of the presence or absence of the reclaimed water other than quantitative tracers (Rueedi et al. 2009). With no halite solution or other sources, $\mathrm{Cl}$ could be used as a conservative tracer to quantitatively estimate the percentage mixing of the reclaimed water in combination with oxygen-18. Therefore, a two-end-member mixing model of reclaimed water and rainwater is applied with Eq. (1) using $\mathrm{Cl}$ and $\delta^{18} \mathrm{O}$ as quantitative tracers. The rainwater endmember $\mathrm{Cl}$ refers to amount-weighted average $\mathrm{Cl}$ concentration in rainwater for Beijing in this sampling campaign. The rainwater end-member $\delta^{18} \mathrm{O}$ refers to amount-weighted average $\delta^{18} \mathrm{O}$ in rainwater for Beijing since 2006. Because the isotope fractionation and $\mathrm{Cl}$ enrichment always happen during the processes of precipitation infiltrated into the groundwater with a depth greater than $20 \mathrm{~m}$, the isotopic and $\mathrm{Cl}$ signatures of GW02 are also used instead of that of precipitation for contrast. Taking into account the effect of evaporation on isotopic composition, $\delta^{18} \mathrm{O}$ of $\mathrm{SW}$ is used as that of the reclaimed water. The secondary evaporation effect on groundwater $\mathrm{Cl}$ and $\delta^{18} \mathrm{O}$ concentrations is assumed negligible with groundwater depth larger than $20 \mathrm{~m}$. The endmember signatures used in the mixing model and the calculated percentage of reclaimed water in affected groundwater are given in Table 2.
The contribution of reclaimed water is based on a mass balance approach refined by examining the contribution of various end-members to groundwater samples using $\mathrm{Cl}$ and $\delta^{18} \mathrm{O}$. In refining the water balance, $\mathrm{Cl}$ is proved to be better tracer than $\delta^{18} \mathrm{O}$ to quantify penetration of the reclaimed water into the groundwater because oxygen- 18 fractionation happens most likely under the influence of evaporation during the replenishment process in semi-arid and arid areas. As shown in Table 2, the contribution of the reclaimed water recharge is significant in the shallow groundwater downhydraulic gradient from the river-channel reservoir, especially in the wet season, more reclaimed water overflow the last dam of the reservoir which results in a higher proportion of reclaimed water in the wet season than that in the dry season. The reclaimed water contributes up to $94 \%$ in groundwater near the natural river channel and to $43 \%$ in groundwater (GW04) far from it. Thus, the importance of reclaimed water to recharge in the groundwater appears to be considerable and will do threat to the drinking water safety without strictly controlling the discharge reclaimed water quality. The groundwater monitoring wells originally were established by the Water Administrative Department in order to provide a national perspective on groundwater quality, and to identify spatial and temporal trends in groundwater chemistry. However, the existing groundwater monitoring wells are inadaptable or not enough to ascertain the contaminant plume of the infiltrated reclaimed water, so more wells along the river channel section and new cross sections are suggested to be established down-gradient of the SW site, and new wells extending to the deeper semi-confined aquifer should be drilled close to the shallow groundwater wells impacted by the reclaimed water.

\section{Conclusions}

As a component in the management of water resources in Beijing, China, reclaimed water is discharged into the historical dried river-channel for landscape purposes. Although the landscape engineering of the reclaimed water was finished in 2006, the amount of water percolating and its effect on groundwater quality are not well understood. A groundwater assessment of an area of Chaobai River Basin in different aquifers adjacent to river-channel fed up reclaimed water on hydrochemistry and water table data showed the recognizable reclaimed water source. The severely affected groundwater is characterised by the largest TDS and the lowest 'deuterium excess' that are consistent with the signature of evapoconcentrated reclaimed water. These results are supported by multivariate statistical analysis (HCA) and stable isotope data. The analysis of groundwater level contours and hydraulic gradient provided further support for the groundwater vectors in and around the study area. 
The classification of hydrochemistry data using Piper diagram and ion ratios' correlation plot and the identification of statistically significant clusters using HCA were largely to obtain a qualitative understanding of the water sources as a starting point for doing the mixing calculations. Groundwater hydrochemistry in Group I is controlled by the aquifer lithology (Factor 1), groundwater hydrochemistry in Group II is affected by the reclaimed water (Factor 2), and groundwater hydrochemistry in Group IV is not contaminated by any nitride. The contribution of reclaimed water is up to $94 \%$ in groundwater near the natural river channel and $43 \%$ in groundwater about $1.7 \mathrm{~km}$ far from it. The amount of reclaimed water percolating and its effect on groundwater quality are considerable. Near the study area, a unique hydraulic setting arises due to the groundwater withdrawal of the Beijing Eighth Waterworks and the flow-through of regional groundwater, which accelerates the flow of regional groundwater such that developmental level with need for mor water is maintained in Beijing. Greater knowledge of the spatial extent of the contaminated groundwater intercepted by the reclaimed water is needed to determine. More wells along the river channel section and new cross sections of monitoring groundwater wells are proposed down-gradient of the raw riverbed to better delineate the contaminant plumes of the infiltrated reclaimed water.

The groundwater mostly replenished by reclaimed water is clustered together into one Group with higher $\mathrm{Cl}(\mathrm{Na}), \mathrm{K}$ and nitirde concentrations. With increasing percentage of the reclaimed water percolating into the groundwater, the water types of the groundwater change from $\mathrm{Ca}-\mathrm{Mg}-\mathrm{HCO}_{3}-\mathrm{Cl}$, via $\mathrm{Ca}-\mathrm{Na}-\mathrm{Mg}-\mathrm{HCO}_{3}-\mathrm{Cl}$ to $\mathrm{Na}-\mathrm{Ca}-\mathrm{Mg}-\mathrm{Cl}-\mathrm{HCO}_{3}$. Due to the downgradient location, the Beijing Eighth Waterworks' groundwater source faces an uncertain future. It should need careful planning and water quality control when implementing the storage of reclaimed water to avoid adverse effects on groundwater quality. Impacts on groundwater quality from reclaimed water recharge are rapid salinization due to increased concentrations of sodium and chloride, and elevated concentrations of organic micropollutants, dissolved organic carbon, nitrate and heavymetals, and high numbers of pathogenic microorganisms (Bekele et al. 2019). However, the water sampling program for this study does not include micropollutants because of the prohibitive costs and resources required to analyse routinely for micropollutants. The study demonstrates the benefits of applying different qualitative and quantitative methods to support proposals to effectively manage reclaimed water for sustainable water use, such as standard graphical and multivariate statistical methods to provide an understanding of water sources as a starting point for mixing calculations, and powerful tracers to calculate the different sources of water. However, the hydrodynamics is complex and should be further investigated to optimally manage and prevent degradation of the water quality. For example, cost-effective methods of adaptive sampling based on real-time monitoring data are being developed for nutrients and could be extended to micropollutants (Schmidt 2018), and a less cost for a well calibrated, flow and contaminant transport modelling method could be developed to determine how many years the effect of mixing with recalimed water going on and its trend impacting on the Beijing Eighth Waterworks in the future.

Supplementary Information The online version contains supplementary material available at https://doi.org/10.1007/s12665-021-09449-1.

Acknowledgements This research was funded by National Natural Science Foundation of China (No. 41730749 and No. 41101031) and MAR-China Managed Aquifer Recharge in North China Plain (No. 17-M08-GEU). The authors express sincere gratitude to Ji Liang for his assistance during the fieldwork. The authors would like to sincerely thank the editor and anonymous reviewers for their reading of the manuscript, and for their valuable suggestions and critical comments.

\section{Compliance with ethical standards}

Conflict of interest The authors declare that they have no conflict of interest.

Open Access This article is licensed under a Creative Commons Attribution 4.0 International License, which permits use, sharing, adaptation, distribution and reproduction in any medium or format, as long as you give appropriate credit to the original author(s) and the source, provide a link to the Creative Commons licence, and indicate if changes were made. The images or other third party material in this article are included in the article's Creative Commons licence, unless indicated otherwise in a credit line to the material. If material is not included in the article's Creative Commons licence and your intended use is not permitted by statutory regulation or exceeds the permitted use, you will need to obtain permission directly from the copyright holder. To view a copy of this licence, visit http://creativecommons.org/licenses/by/4.0/.

\section{References}

Bajjali W, Al-Hadidi K, Ismail MM (2017) Water quality and geochemistry evaluation of groundwater upstream and downstream of the Khirbet Al-Samra wastewater treatment plant/Jordan. Appl Water Sci 7(1):53-69. https://doi.org/10.1007/s13201-014-0263-x

Beh EJ (2012) Biplots in practice. J R Stat Soc Ser A (Stat Soc) 175:1073-1074. https://doi.org/10.1111/j.1467-985X.2012.01069 5.x

Bekele E, Toze S, Patterson B, Devine B et al (2009) Chapter 1design and operation of infiltration galleries and water quality changes, In: Determining requirements for managed aquifer recharge in Western Australia. 1, CSIRO: Water for a Healthy Country National Research Flagship

Bekele E, Zhang YH, Donn M et al (2019) Inferring groundwater dynamics in a coastal aquifer near wastewater infiltration ponds and shallow wetlands (Kwinana, Western Australia) using combined hydrochemical, isotopic and statistical approaches. J Hydrol 568:1055-1070 
Braak CF (1990) Interpreting canonical correlation analysis through biplots of structure correlations and weights. Psychometrika 55:519-531. https://doi.org/10.1007/BF02294765

Burg A, Guttman J (2019) Mitigation of downstream propagation of contaminated water in a carbonate aquifer - the northeastern Negev desert, Israel. Sci Total Environ 654:550-562

Cai X, Luan Y, Guo G et al (2009a) 3D quaternary geological structure of Beijing plain. Geol China 36:1021-1029

Cai X, Luan Y, Guo G et al (2009b) Geological system in Beijing plain area. City Geol 4:6-12

Candela L, Fabregat S, Josa A et al (2007) Assessment of soil and groundwater impacts by treated urban wastewater reuse. A case study: application in a golf course (Girona, Spain). Sci Total Environ 374:26-35. https://doi.org/10.1016/j.scitotenv.2006.12.028

Cerny BA, Kaiser HF (1977) A study of a measure of sampling adequacy for factor-analytic correlation matrices. Multivar Behav Res 12:43-47. https://doi.org/10.1207/s15327906mbr1201_3

Ceschin S, Aleffi M, Bisceglie S et al (2012) Aquatic bryophytes as ecological indicators of the water quality status in the Tiber River basin (Italy). Ecol Indic 14:74-81. https://doi.org/10.1016/j.ecoli nd.2011.08.020

Charles AK, Belitz K (2003) Tracing reclaimed water in the Menifee, Winchester, and Perris-South Ground-Water Subbasins, Riverside County, California. US GEOLOGICAL SURVEY, WaterResources Investigations Report 03-4039

Dansgaard W (1964) Stable isotopes in precipitation. Tellus 16:436-468

Engelhardt I, Barth JAC, Bol R et al (2014) Quantification of long-term wastewater fluxes at the surface water/groundwater-interface: an integrative model perspective using stable isotopes and acesulfame. Sci Total Environ 466:16-25. https://doi.org/10.1016/j.scito tenv.2013.06.092

Estevez E, Cabrera MD, Fernandez-Vera JR et al (2016) Monitoring priority substances, other organic contaminants and heavy metals in a volcanic aquifer from different sources and hydrological processes. Sci Total Environ 551:186-196. https://doi.org/10.1016/j. scitotenv.2016.01.177

Filippini M, Stumpp C, Nijenhuis I et al (2015) Evaluation of aquifer recharge and vulnerability in an alluvial lowland using environmental tracers. J Hydrol 529:1657-1668. https://doi.org/10.1016/j. jhydrol.2015.07.055

Gbolo P, Gerla P (2013) Statistical analysis to characterize transport of nutrients in groundwater near an abandoned feedlot. Hydrol Earth Syst Sci 17:4897-4906. https://doi.org/10.5194/ hess-17-4897-2013

Ginige MP, Kaksonen AH, Morris C et al (2013) Bacterial community and groundwater quality changes in an anaerobic aquifer during groundwater recharge with aerobic recycled water. Fems Microbiol Ecol 85:553-567. https://doi.org/10.1111/1574-6941.12137

Guler C, Thyne GD, McCray JE et al (2002) Evaluation of graphical and multivariate statistical methods for classification of water chemistry data. Hydrogeol J 10:455-474. https://doi.org/10.1007/ s10040-002-0196-6

Hirsch RM, Slack JR, Smith RA (1982) Techniques of trend analysis for monthly water quality data. Water Resour Res 18:107-121. https://doi.org/10.1029/WR018i001p00107

Hounslow A (1995) Water quality data: analysis and interpretation. CRC Press, Boca Raton

Huang F, Wang XQ, Lou LP et al (2010) Spatial variation and source apportionment of water pollution in Qiantang River (China) using statistical techniques. Water Res 44:1562-1572. https:// doi.org/10.1016/j.watres.2009.11.003

Jackson JE (1991) A user's guide to principal components. Wiley, New York

Kass A, Gavrieli I, Yechieli Y et al (2005) The impact of freshwater and wastewater irrigation on the chemistry of shallow groundwater: a case study from the Israeli Coastal Aquifer. J Hydrol 300:314331. https://doi.org/10.1016/j.jhydrol.2004.06.013

Katz BG, Griffin DW (2008) Using chemical and microbiological indicators to track the impacts from the land application of treated municipal wastewater and other sources on groundwater quality in a karstic springs basin. Environ Geol 55:801-821. https://doi. org/10.1007/s00254-007-1033-y

La Salle CLG, Vanderzalm J, Hutson J et al (2005) Isotope evolution and contribution to geochemical investigations in aquifer storage and recovery: a case study using reclaimed water at Bolivar, South Australia. Hydrol Process 19:3395-3411. https://doi.org/10.1002/ hyp. 5977

Lanzante JR (1996) Resistant, robust and non-parametric techniques for the analysis of climate data: theory and examples, including applications to historical radiosonde station data. Int J Climatol 16:1197-1226. https://doi.org/10.1002/(SICI)1097-0088(19961 1)16:11\%3c1197::AID-JOC89\%3e3.0.CO;2-L

Lapworth DJ, Baran N, Stuart ME et al (2012) Emerging organic contaminants in groundwater: a review of sources, fate and occurrence. Environ Pollut 163:287-303. https://doi.org/10.1016/j. envpol.2011.12.034

Liu JR, Song XF, Fu GB et al (2011) Precipitation isotope characteristics and climatic controls at a continental and an island site in Northeast Asia. Clim Res 49:29-44. https://doi.org/10.3354/ Cr01013

Liu P, Hoth N, Drebenstedt C et al (2017) Hydro-geochemical paths of multi-layer groundwater system in coal mining regionsusing multivariate statistics and geochemical modeling approaches. Sci Total Environ 601-602:1-14

Masoud AA (2014) Groundwater quality assessment of the shallow aquifers west of the Nile Delta (Egypt) using multivariate statistical and geostatistical techniques. J Afr Earth Sci 95:123-137. https://doi.org/10.1016/j.jafrearsci.2014.03.006

Moeck C, Radny D, Borer P et al (2016) Multicomponent statistical analysis to identify flow and transport processes in a highlycomplex environment. J Hydrol 542:437-449

Mohamed I, Othman F, Ibrahim AIN et al (2015) Assessment of water quality parameters using multivariate analysis for Klang River basin, Malaysia. Environ Monit Assess 187(1):4182. https ://doi.org/10.1007/S10661-014-4182-Y

Murgulet D, Cook M, Murgulet V (2016) Groundwater mixing between different aquifer types in a complex structural setting discerned by elemental and stable isotope geochemistry. Hydrol Process 30:410-423. https://doi.org/10.1002/hyp.10589

Narr CF, Singh H, Mayer P et al (2019) Quantifying the effects of surface conveyance of treated wastewater effluent on groundwater, surface water, and nutrient dynamics in a large river floodplain. Ecol Eng 129:123-133

Page D, Dillon P, Toze S et al (2010) Valuing the subsurface pathogen treatment barrier in water recycling via aquifers for drinking supplies. Water Res 44:1841-1852. https://doi.org/10.1016/j. watres.2009.12.008

Parinet J, Rodriguez MJ, Serodes JB (2013) Modelling geosmin concentrations in three sources of raw water in Quebec, Canada. Environ Monit Assess 185:95-111. https://doi.org/10.1007/ s10661-012-2536-X

Peng TR, Lu WC, Chen KY et al (2014) Groundwater-recharge connectivity between a hills-and-plains' area of western Taiwan using water isotopes and electrical conductivity. J Hydrol 517:226-235. https://doi.org/10.1016/j.jhydrol.2014.05.010

Piper AM (1944) A graphic procedure in the geochemical interpretation of water-analyses. Eos Trans Am Geophys Un 25:914-923

Quiers M, Batiot-Guilhe C, Bicalho C et al (2014) Characterisation of rapid infiltration flows and vulnerability in a karst aquifer using a decomposed fluorescence signal of dissolved organic 
matter. Environ Earth Sci 71:553-561. https://doi.org/10.1007/ s12665-013-2731-2

Rao GT, Rao VVSG, Rao YS et al (2013) Study of hydrogeochemical processes of the groundwater in Ghatprabha river sub-basin, Bagalkot District, Karnataka, India. Arab J Geosci 6:24472459. https://doi.org/10.1007/s12517-012-0535-4

Redwan M, Moneim AAA, Amra MA (2016) Effect of water-rock interaction processes on the hydrogeochemistry of groundwater west of Sohag area, Egypt. Arab J Geosci 9:111. https://doi. org/10.1007/S12517-015-2042-X

Rueedi J, Cronin AA, Morris BL (2009) Estimation of sewer leakage to urban groundwater using depth-specific hydrochemistry. Water Environ J 23:134-144. https://doi.org/10.111 $1 / \mathrm{j} .1747-6593.2008 .00119 . x$

Schmidt TC (2018) Recent trends in water analysis triggering future monitoring of organic micropollutants. Anal Bioanal Chem 410(17):3933-3941. https://doi.org/10.1007/s0021 6-018-1015-9

Singh CK, Shashtri S, Rina K et al (2013) Chemometric analysis to infer hydro-geochemical processes in a semi-arid region of India. Arab J Geosci 6:2915-2932. https://doi.org/10.1007/s1251 7-012-0597-3

Srinivasamoorthy K, Chidambaram S, Prasanna MV et al (2008) Identification of major sources controlling groundwater chemistry from a hard rock terrain - a case study from Mettur taluk, Salem district, Tamil Nadu, India. J Earth Syst Sci 117:49-58. https:// doi.org/10.1007/s12040-008-0012-3

Vanderzalm JL, Page DW, Barry KE et al (2013) Application of a probabilistic modelling approach for evaluation of nitrogen, phosphorus and organic carbon removal efficiency during four successive cycles of aquifer storage and recovery (ASR) in an anoxic carbonate aquifer. Water Res 47:2177-2189. https://doi. org/10.1016/j.watres.2013.01.038

Vodyanitskii YN, Yakovlev AS (2016) Contamination of soils and groundwater with new organic micropollutants: a review. Eurasian Soil Sci 49:560-569. https://doi.org/10.1134/S106422931 6050148

Wu DJ, Lin XY, Wang JS et al (2012) Recharge processes and groundwater evolution of multiple aquifers, Beijing, China. Proc Ist Civil Eng Water Manag 165:411-424. https://doi.org/10.1680/ wama. 10.00113

Yamanaka T, Shimada J, Tsujimura M et al (2011) Tracing a confined groundwater flow system under the pressure of excessive groundwater use in the lower central plain, Thailand. Hydrol Process 25:2654-2664. https://doi.org/10.1002/hyp.8007

Yidana SM, Banoeng-Yakubo B, Sakyi PA (2012) Identifying key processes in the hydrochemistry of a basin through the combined use of factor and regression models. J Earth Syst Sci 121:491-507. https://doi.org/10.1007/s12040-012-0163-0

Yu JH (1990) Geochemistry of rapakivi granite suite in a proterozoic rift in Beijing and its vicinity. Acta Geol Sin 64(4):322-336

Zheng FD, Liu LC, Li BH et al (2015) Effects of reclaimed water use for scenic water on groundwater environment in a multilayered aquifer system beneath the Chaobai River, Beijing, China: case study. J Hydrol Eng 20(3):B5014003. https://doi.org/10.1061/ (Asce)He.1943-5584.0001052

Publisher's Note Springer Nature remains neutral with regard to jurisdictional claims in published maps and institutional affiliations. 